\title{
Helicobacter pylori induced interleukin-8 expression in gastric epithelial cells is associated with CagA positive phenotype
}

\author{
J E Crabtree, A Covacci, S M Farmery, Z Xiang, D S Tompkins, S Perry, I J D Lindley, \\ R Rappuoli
}

\begin{abstract}
Aims-To use a range of natural phenotypically variant strains of Helicobacter pylori with disparate CagA and VacA (vacuolating cytotoxin) expression to determine which bacterial factors are more closely associated with epithelial interleukin-8 (IL-8) induction.

Methods-Gastric epithelial cells (AGS and KATO-3) were co-cultured with five $H$ pylori strains which were variously shown to express the cagA gene/CagA protein, VacA and/or to exhibit biological cytotoxicity. Secreted IL-8 was assayed by enzyme leaked immunosorbent assay (ELISA) and IL-8 messenger RNA (mRNA) was assayed using a reverse transcription polymerase chain reaction based technique (RT-PCR).
\end{abstract}

Results-Strains expressing CagA, including a variant strain (D931) which is non-cytotoxic and does not express the VacA protein, were found to upregulate epithelial IL-8 secretion and gene expression. In contrast, strains with no CagA expression, even in the presence of VacA and/or biological cytotoxicity, (G104, BA142), failed to induce IL-8 protein or mRNA above control values.

Conclusions-These results strongly support a role for $H$ pylori CagA or coexpressed factors other than the cytotoxin in upregulation of gastric epithelial IL-8. Increased epithelial IL-8 secretion and concomitant neutrophil chemotaxis and activation in addition to direct cytotoxicity may be an important factor in tissue damage and ulceration.

(F Clin Pathol 1995;48:41-45)

Department of Clinical Medicine, St James's University Hospital, Leeds LS9 7TF

J E Crabtree

S M Farmery

$S$ Perry

Public Health Laboratory, Leeds D S Tompkins

Sandoz Research Institute, Vienna, Austria

I J D Lindley

Immunobiological Research Institute, Siena, Italy A Covacci

Z Xiang

R Rappuoli

Correspondence to:

Dr J E Crabtree.

Accepted for publication

7 July 1994 associated with both increased epithelial IL-8 expression $^{1}$ and mucosal secretion of $\mathrm{IL}-8 .{ }^{6}$ The bacterium will directly upregulate IL-8 messenger RNA (mRNA) expression and IL-8 pylori. Infection with this bacterium is characterised by neutrophil infiltration into the gastric mucosa and epithelial layer ${ }^{4}$ and such cellular responses may be important in tissue damage and ulceration. ${ }^{5} \mathrm{H}$ pylori infection is
The epithelium of the human gastroduodenal mucosa expresses interleukin-8 (IL-8), for
potent chemotactic and activating factor for neutrophils. ${ }^{23}$ Interleukin-8 may be functionally involved in regulating neutrophil responses to the gastric pathogen Helicobacter protein secretion in gastric epithelial cell lines. ${ }^{7}$ This response appears to be restricted to epithelial cell lines from gastric sites within the gastrointestinal tract, suggesting a specific host-bacteria interaction related to the specificity of colonisation. ${ }^{7}$

Although $H$ pylori shows extreme genomic variability, ${ }^{8}$ recent studies have shown that strains can be divided into two major groups, one in which both a $128 \mathrm{kDa}$ antigen (CagA) and a vacuolating cytotoxin (VacA) are expressed, and another which does not produce these proteins. ${ }^{9-13}$ Previous studies have linked bacterial cytotoxicity, ${ }^{12}$ mucosal IgA, ${ }^{14}$ and systemic $\operatorname{IgG}^{15} 16$ recognition of the CagA protein (also defined as a $120-130 \mathrm{kDa}$ antigen), with peptic ulceration strongly suggesting these strains have greater ulcerogenic potential. Although others have argued that there are no ulcerogenic strains of $H$ pylori and host responses are critical in ulcerogenesis, ${ }^{17}$ induction of epithelial IL-8 by $H$ pylori was recently shown to be strain specific. ${ }^{7}$ Interestingly, $H$ pylori strains expressing the CagA $128 \mathrm{kDa}$ protein and the strongly associated vacuolating cytotoxin induce IL-8 secretion from gastric epithelial cells but minimal secretion occurs after culture with noncytotoxic CagA negative strains. ${ }^{7}$ In this study we have used recently identified phenotypic variants of $H$ pylori with disparate CagA and cytotoxin expression (Xiang Z et al, 1994, unpublished observations) to investigate which of these two virulence factors is associated with IL-8 induction in two gastric epithelial cell lines.

\section{Methods}

Five $H$ pylori strains were used: $H$ pylori NCTC 11637 and four clinical isolates G50, BA142, D931, and G104. Cytotoxic NCTC 11637, which expresses the CagA protein and induces epithelial IL-8 production, and noncytotoxic CagA negative $\mathrm{G} 50^{7}$ were the positive and negative controls, respectively. The presence of the $\operatorname{cag} A$ gene was determined by the polymerase chain reaction (PCR) ${ }^{18}{ }^{19}$ using cag $A$ gene specific primers ${ }^{10}$ and by Southern blotting using two fragments of the $\operatorname{cag} A$ gene spanning nucleotides 521 to 1840 and nucleotides 1460 to 2620 as probes. ${ }^{9}$ CagA protein expression was characterised by western blotting using mouse polyclonal antisera raised against electroeluted antigen isolated from NCTC 11637 bacterial extracts ${ }^{9}$ and rabbit antisera to the recombinant fragment 17/12 of CagA. ${ }^{9}$ The fusion protein was 
Genotype/phenotype of $H$ pylori strains

\begin{tabular}{llllll}
\hline $\begin{array}{l}\text { H pylori } \\
\text { strain }\end{array}$ & cagA gene & CagA protein & $\begin{array}{l}\text { Cytotoxin } \\
\text { bioactivity }\end{array}$ & vacA gene & VacA protein \\
\hline NCTC 11637 & + & + & + & + & + \\
G50 & - & - & - & + & - \\
G104 & - & - & + & + & + \\
D931 & + & + & - & + & - \\
BA142 & - & - & + & + & - \\
\hline
\end{tabular}

generated by cloning the region of the $\operatorname{cag} A$ gene between nucleotides 2776 and 3467 into the MS2 polymerase gene carried in the $\mathrm{pEX}$ $34 \mathrm{~B}$ plasmid vector. ${ }^{20}$ Water extracts of bacterial cells were assessed for cytotoxicity against HeLa cells in vitro, as previously described. ${ }^{21}$ The presence of the VacA protein was determined by western blotting and rabbit antisera specific for recombinant VacA. ${ }^{13}$

Epithelial co-culture experiments were undertaken without prior knowledge of the phenotypic characteristics of the variant strains. For these experiments, bacteria were grown on blood agar base Number 2 (Oxoid, Basingstoke, Hampshire) including $7 \%$ fresh horse blood. Bacteria were harvested on day 4 into phosphate buffered saline (PBS). After centrifugation, bacteria were resuspended at $2.5 \times 10^{7} / \mathrm{ml}$ in RPMI 1640 (ICN-Flow Laboratories, High Wycombe, Bucks) supplemented with $10 \%$ heat inactivated fetal calf serum (FCS) (Sera Lab, Crawley, Surrey) and used immediately.

\section{STIMULATION OF GASTRIC EPITHELIAL CELI} LINES WITH $H$ PYLORI

Two gastric epithelial cell lines KATO-3 (European Collection of Animal Cell Cultures (ECACC), Salisbury, Wiltshire) and AGS (ECACC) were routinely maintained in RPMI 1640 supplemented with $10 \%$ FCS and $40 \mu \mathrm{g} / \mathrm{ml}$ gentamicin. AGS cells were plated into 24 well plates (ICN-Flow) at a density of $1 \times 10^{5} / \mathrm{ml}$ and cultured for three

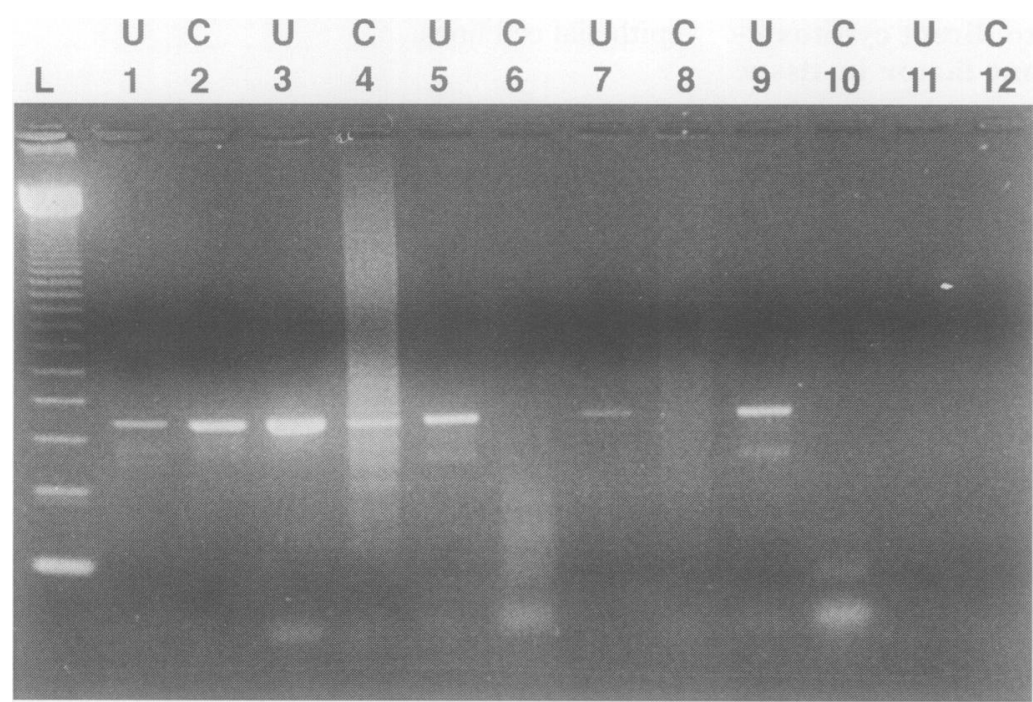

Figure 1 PCR amplification of cagA gene (C) and urease gene $A(U)$ (PCR control) in the H pylori NCTC 11637 (lanes 1 and 2), D931 (lanes 3 and 4), BA142 (lanes 5 and 6), G104 (lanes 7 and 8), and G50 (lanes 9 and 10) strains. Lanes 11 and 12 contain DNA negative controls; lane $L$ contains a 100 base pair ladder (Gibco-BRL). NCTC 11637 and $D 931$ are positive for the cagA gene.

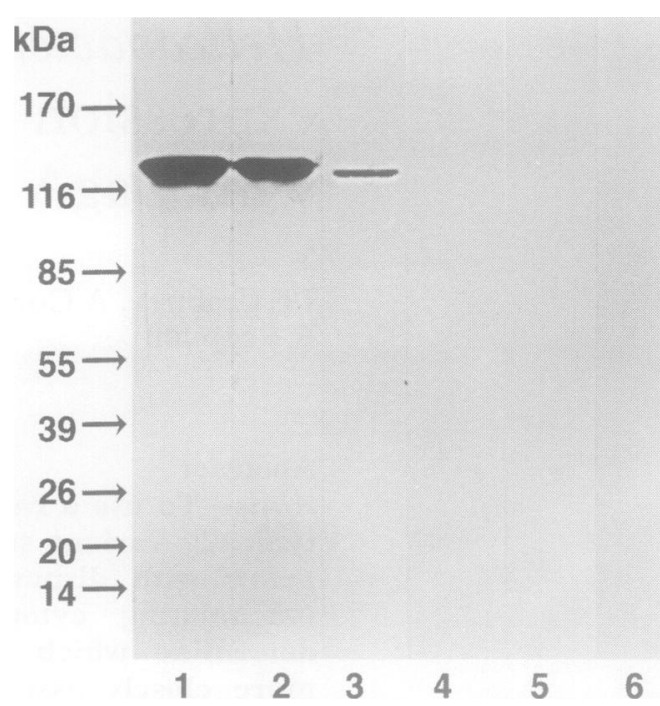

Figure 2 Western blot analysis of whole cell extracts from six different $H$ pylori strains: NCTC 11637 (lane 1) 60190 (lane 2), D931 (lane 3), BA142 (lane 4), G104 (lane 5), and G50 (lane 6). The CagA antigen was detected with a mouse polyclonal antiserum raised against the electroeluted antigen, isolated from NCTC 11637 bacterial extracts. Samples were separated on a PAGE$S D S$ gradient gel and transferred to a nitrocellulose membrane. Immunocomplexes were revealed with ECL (Amersham). BA142, G104, and G50 are cagA/CagA negative strains. BA142 and G104 were positive in the in vitro assay for vacuolating activity.

days to confluence (approximately $5 \times$ $10^{5} / \mathrm{ml}$ ). KATO-3 cells, which are non-adherent, were resuspended in RPMI 1640 containing $10 \%$ FCS without gentamicin and used at a final concentration of $5 \times 10^{5} / \mathrm{ml}$. After removal of the gentamicin containing media from AGS monolayers, gastric epithelial cells (AGS and KATO-3) were cultured in quadruplicate either alone or with bacterial preparations for 24 hours at $37^{\circ} \mathrm{C}$ in a $95 \%$ air, $5 \% \quad \mathrm{CO}_{2}$ humidified incubator. Supernatants were aspirated at 24 hours and stored at $-70^{\circ} \mathrm{C}$ until assayed using an enzyme linked immunosorbent assay (ELISA). In parallel experiments KATO-3 cells were cultured with $H$ pylori strains for three hours for examination of cellular IL-8 messenger RNA (mRNA) expression.

\section{IL-8 ELISA}

Interleukin- 8 in cell culture supernatants was assayed in duplicate by ELISA as described previously $^{22}$ using a murine monoclonal antibody to IL-8 and a phosphatase conjugated goat anti-IL8 polyclonal antibody. Concentrations of IL-8 were determined from a standard curve of recombinant IL- $8^{3}$ (Sandoz, Vienna, Austria) and concentrations were expressed as $\mathrm{ng} / \mathrm{ml}$. The detection limit of the ELISA was $62 \mathrm{pg} / \mathrm{ml}$.

\section{IL-8 MRNA EXPRESSION}

Interleukin-8 mRNA expression was determined as described previously. ${ }^{7}$ Briefly, after three hours of bacterial co-culture, total RNA from KATO-3 cells was extracted using RNAzolB (Biogenesis Ltd, Bournemouth) and mRNA was reverse transcribed using MMLV reverse transcriptase primed with oligo dT15. The complimentary DNA was 

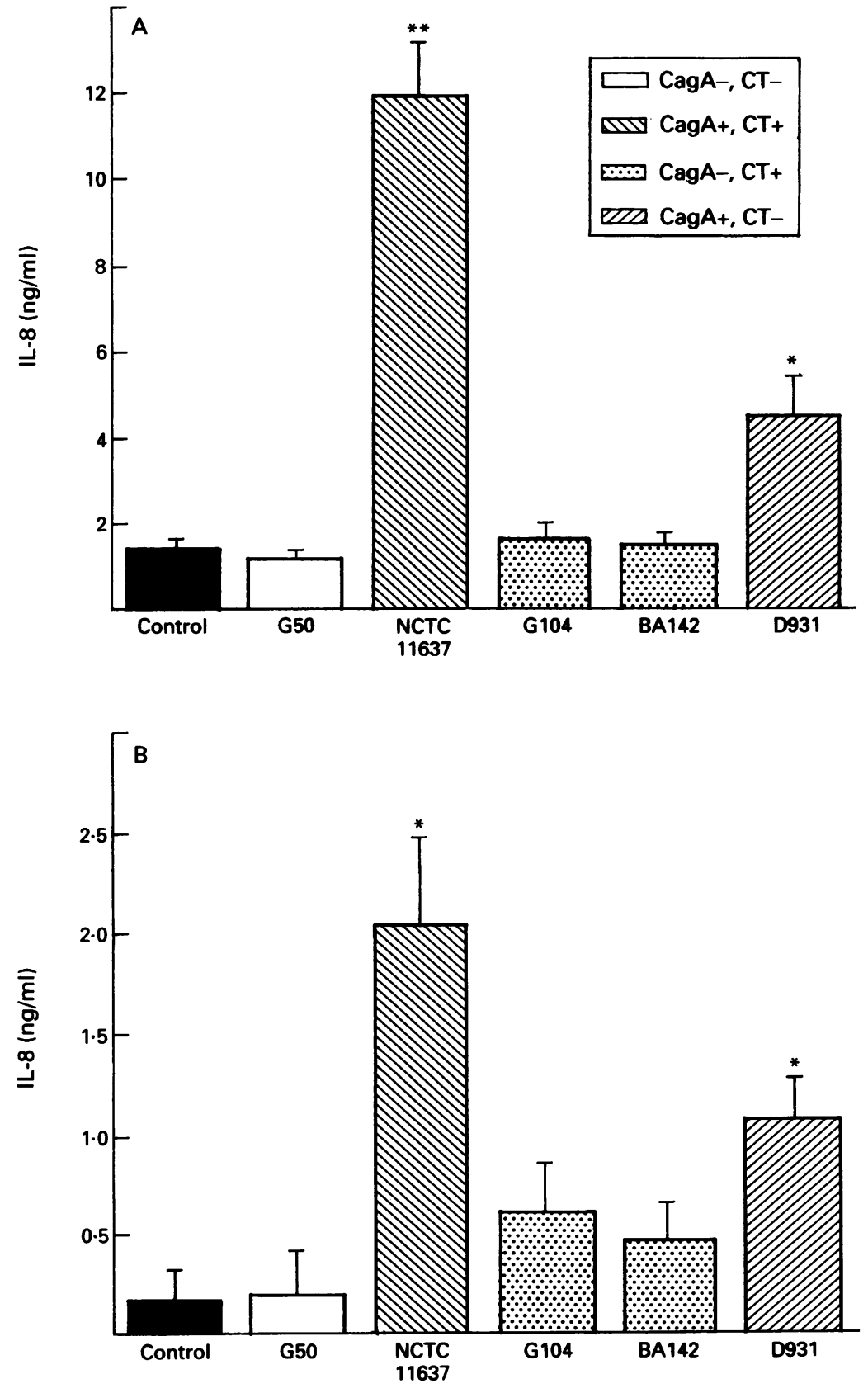

Figure 3 Secretion of IL-8 from (A) KATO-3 and (B) AGS gastric epithelial cell lines over 24 hours following stimulation with the following $H$ pylori strains: G50, NCTC

11637, G104, BA142, and D931. The figures show the mean (SEM) of five independent experiments. ${ }_{p}<0.02$ from control, ${ }^{*_{p}}<0.01$ from control. $C T \pm=$ strains with or without cytotoxin bioactivity. negative (G50) controls is shown in the table. One of the variant strains, D931, which was non-cytotoxic and did not express VacA, was positive for the $\operatorname{cag} A$ gene on PCR (fig 1) and Southern blotting, and expressed the CagA protein (fig 2). Strains G104 and BA142 showed no expression of the $\operatorname{cag} A$ gene on PCR (fig 1) or Southern blotting, and did not express the CagA protein (fig 2), although both strains showed biological cytotoxicity and G104 expressed the VacA protein (table). The absence of VacA protein in western blots of the biologically cytotoxic BA142 strain may reflect disparity between immunoreactive and biologically functional epitopes.

EFFECTS OF $H$ PYLORI STRAINS ON GASTRIC EPITHELIAL IL-8 SECRETION

Secretion of IL- 8 by KATO-3 and AGS gastric epithelial cell lines over the 24 hours following stimulation with $H$ pylori strains is shown in figs $3 A$ and $B$, respectively. In KATO-3 cells significant secretion of IL-8, when compared with cell only control cultures, was observed after stimulation with the VacA positive/CagA positive NCTC 11637 strain $(\mathrm{p}<0.01)$ and the CagA positive/VacA negative D931 strain $(\mathrm{p}<0.02)$ (fig $3 \mathrm{~A})$. The CagA negative/VacA negative G50 strain and cytotoxic CagA negative strains, G104 and BA142, did not induce secretion of IL-8 from KATO-3 cells. In KATO-3 cells IL-8 secretion induced by NCTC 11637 and D931 was significantly greater $(p<0.05)$ than that induced by G50, BA142, and G104. In the AGS cell line, as previously observed, ${ }^{7}$ the NCTC 11637 strain induced lower levels of IL-8 secretion than in the KATO-3 cells (fig 3B). In AGS cells significant IL-8 secretion, when compared with cell only controls, was observed after co-culture with NCTC 11637 and D931 $(p<0.02)$ but not G50, BA142, and G104 (fig 3B).

EFFECTS OF $H$ PYLORI STRAINS ON IL-8 MRNA EXPRESSION IN KATO-3 CELLS

Initial time course studies revealed optimum IL-8 mRNA expression in KATO-3 cells three hours following stimulation with $H$ pylori. Figure 4 shows the ratio of IL- 8 mRNA to G3PDH PCR products in KATO-3 cells three hours after stimulation with the five $H$ pylori strains. A significant increase in the ratio of IL-8 to G3PDH PCR products was evident after culture with NCTC 11637 ( $p<0.01)$ and D931 ( $<<0.05)$ compared with cell only controls. Stimulation of KATO-3 cells with strains G50, G104, and BA142 did not result in an increase in the IL-8 to G3PDH ratio (figs 4 and 5).

\section{Discussion}

The induction of epithelial IL-8 production by $H$ pylori occurs in a strain specific manner, ${ }^{7}$ with those strains expressing the CagA protein and the strongly associated vacuolating cytotoxin stimulating IL-8 secretion. As CagA and cytotoxin expression are very closely associated, ${ }^{9-11}$ our previous studies ${ }^{7}$ could not

\section{Results}

H PYLORI STRAIN PHENOTYPE

The phenotype of the three variant strains, together with the positive (NCTC 11637) and 


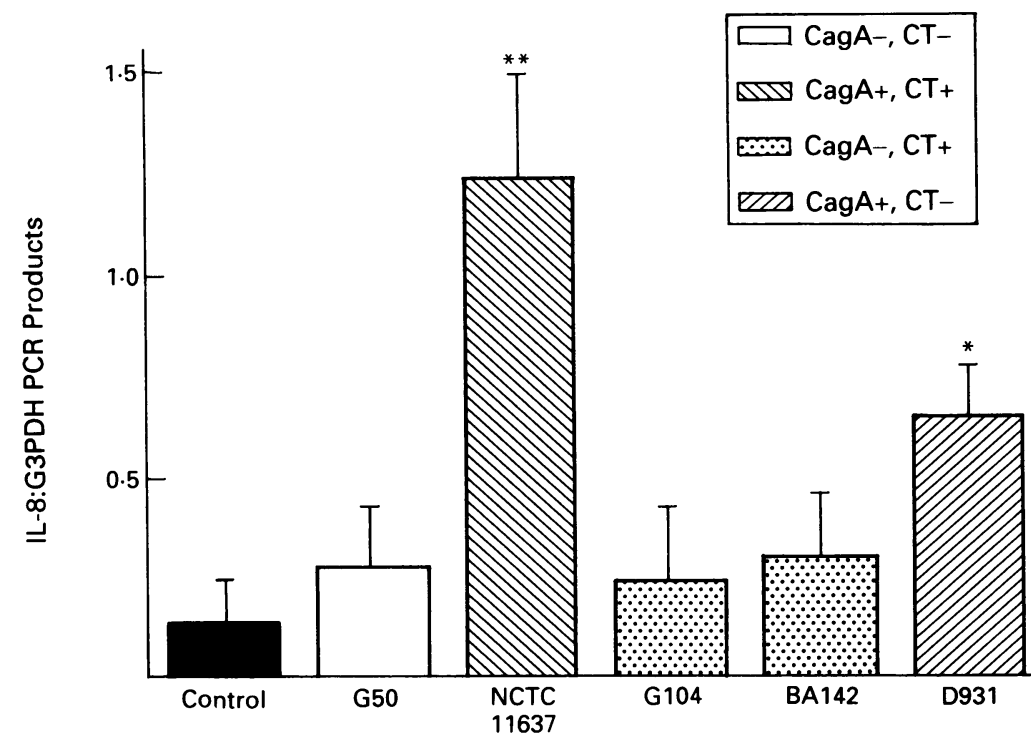

Figure 4 Effects of $H$ pylori strains on $I L-8 m R N A$ expression in KATO-3 gastric epithelial cells. The results show the mean (SEM) ratio of IL-8 to G3PDH PCR products $(n=5)$ three hours after culture with G50, NCTC 11637, G104, BA142, and D931. $C T \pm=$ strains with or without cytotoxin bioactivity. ${ }^{\star} p<0.05,{ }^{\star}{ }^{\star} p<0.01$.

determine which bacterial factor was more closely linked with IL-8 induction. However, monensin, a carboxylic ionophore, which blocks cytoplasmic vacuolisation induced by $H$ pylori cytotoxin, ${ }^{23}$ did not specifically inhibit epithelial IL-8 induction, ${ }^{7}$ suggesting other bacterial factors associated with cytotoxin expression may be important in upregulating IL-8 secretion.

The role of the highly immunogenic CagA protein, which shows size heterogeneity, ${ }^{9}$ in the pathogenesis of $H$ pylori infection is unclear. Earlier studies have shown that noncytotoxic strains almost invariably lack the cag $A$ gene, suggesting that the CagA protein may be necessary either for transcription or production of a functional cytotoxin. ${ }^{910}$ However, recent molecular screening of a large number of strains has identified naturally occurring phenotypic variants in which

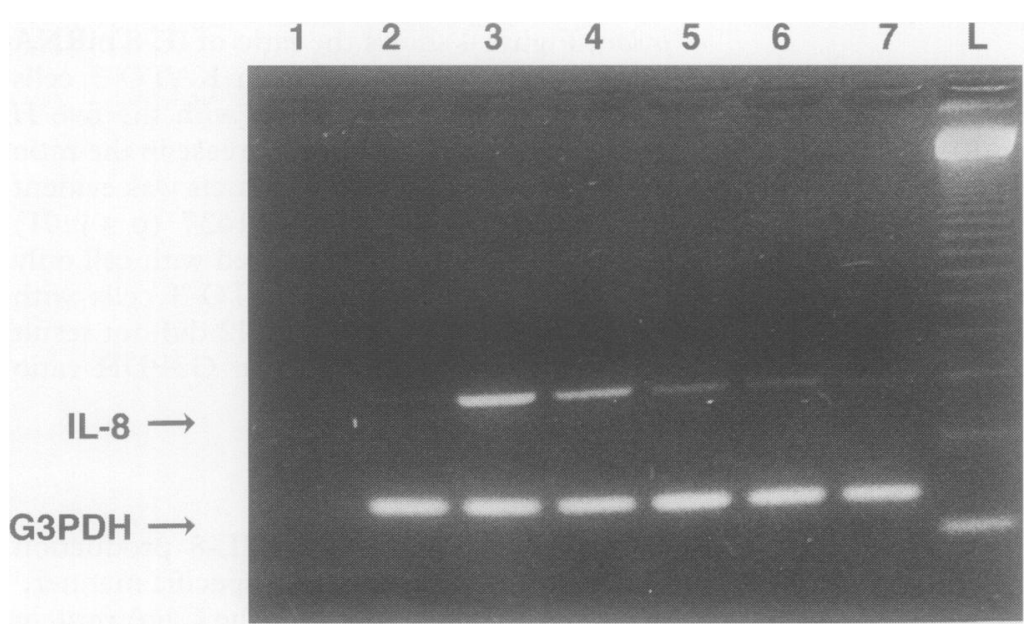

Figure $5 \quad P C R$ analysis of $m R N A$ using primers specific for $I L-8$ (369 base pairs) and G3PDH (157 base pairs) in KATO-3 gastric epithelial cells three hours after stimulation with $H$ pylori. Lane 1, DNA negative control; lane 2, cell only control; lane 3, NCTC 11637; lane 4, D931; lane 5, BA142; lane 6, G104; lane 7, G50; and lane L, 123 base pair ladder (Gibco-BRL). the CagA and VacA proteins are not coexpressed (Xiang $\mathrm{Z}$ et al, 1994, unpublished observations), suggesting that cag $A$ gene expression is not essential for functional cytotoxicity. In contrast to $\operatorname{cag} A$, the $v a c A$ gene is present in all strains of $H$ pylori; however, the gene is silent in non-cytotoxic strains which do not secrete the $94 \mathrm{kDa}$ active VacA protein. ${ }^{13}$ BA142, although biologically cytotoxic, did not possess the immunoreactive VacA protein. This may reflect either a disparity between biological and immunological functional epitopes in this strain, or the synthesis of a labile variant of the vacuolating cytotoxin. Additional data supporting the latter hypothesis is that northern slot blot analysis of mRNA from BA142 shows that the vacA gene is actively transcribed in this strain.

In the present study using the natural phenotypic variants of $H$ pylori, we show that CagA expression, and not VacA expression, is associated with upregulation of epithelial IL-8 mRNA expression and stimulation of IL-8 protein secretion. In both AGS and KATO-3 epithelial cell lines the CagA positive/cytotoxin negative D931 strain increased IL-8 mRNA expression and induced IL-8 protein secretion, albeit at lower levels than NCTC 11637. Cytotoxic strains lacking the $\operatorname{cag} A$ gene did not induce IL-8. Quantitative differences in CagA expression, or co-expressed surface factors, may account for differing levels of IL-8 induction.

The lack of induction of IL- 8 by CagA negative cytotoxic strains is of particular interest as oral administration of purified cytotoxin (VacA) to mice induces gastric epithelial lesions and cell necrosis but not inflammatory cell infiltration. ${ }^{13}$ Infection with cytotoxic strains of $H$ pylori, however, has recently been associated with increased polymorph infiltration in human antral mucosa. ${ }^{24}$ As epithelial IL-8 induction does not relate to cytotoxin expression, this observation may be secondary to expression of other bacterial factors. Our previous studies have demonstrated a strong association between mucosal IgA recognition of the CagA protein and antral polymorph infiltration. ${ }^{14}$ Induction of gastric epithelial IL- 8 by the CagA protein, or co-expressed surface factors other than the cytotoxin, may be an important factor regulating neutrophil chemotaxis and may explain these histopathological observations.

Both host and bacterial factors are important for determining the extent of mucosal cellular responses to $H$ pylori infection. Bacterial products ${ }^{25-29}$ and a range of inflammatory mediators such as $\mathrm{C} 5 \mathrm{a}$, leukotriene $\mathrm{B} 4$, and platelet activating factor, ${ }^{30}$ in addition to IL-8, may also regulate polymorph infiltration and activation in response to $H$ pylori infection. Previous studies have linked both immunological recognition of the CagA protein $^{914}{ }^{16}$ and bacterial cytotoxicity ${ }^{12}$ with peptic ulceration. The inhibition of in vitro cytotoxicity by gastric $H$ pylori specific IgA antibodies $^{31}$ suggests that the cytotoxin may not be the only factor involved in the pathogenesis of peptic ulceration. 
Neutrophils are strongly linked with peptic ulceration and may be important mediators of mucosal damage.$^{4}$ Interleukin-8, and related members of the chemokine family, have been implicated in the pathogenesis of several inflammatory and infectious conditions characterised by neutrophil infiltration ${ }^{32}$ and the importance of the epithelium, the primary host-bacteria interface, as a source of immunoregulatory peptides is becoming increasingly recognised. ${ }^{33-35}$ Differential induction of IL-8 in gastric epithelial cells by $H$ pylori strains may be an important factor determining the cellular response to infection.

This study was undertaken with financial assistance of the Yorkshire Regional Health Authority. We thank Drs N Figura Yorkshire Regional Health Authority. We thank Drs N Figura
and D Dwarakanath for kindly providing the $H$ pylori strains and Dr P Peichl for helpful discussion.

1 Crabtree JE, Wyatt JI, Trejdosiewicz LK, Peichl P, Nichols PN, Ramsay N, et al. Interleukin-8 expression in Helicobacter pylori infected, normal, and neoplastic gastroduodenal mucosa. $\mathcal{F}$ Clin Pathol 1994;47:61-6.

2 Matsushima K, Morishita K, Yoshimura T, Lavu S, Kobayashi Y, Lew W, et al. Molecular cloning of human monocyte-derived neutrophil chemotactic factor monocyte-derived neutrophil chemotactic factor
(MDNCF) and induction of MDNCF by interleukin-1 and tumour necrosis factor. $\mathcal{F}$ Exp Med 1988;167: 1883-93.

3 Lindley I, Aschauer H, Siefert JM, Lam C, Brunowsky W, Konatzki E, et al. Synthesis and expression in Escherichia coli of the gene encoding monocyte-derived neutrophil activating factor: biological equivalence between natural Acad Sci USA 1988;85:9199-203.

4 Dixon MF. Helicobacter pylori and peptic ulceration: histopathological aspects. $\mathcal{F}$ Gastroenterol Hepatol 1991;6: 125-30.

5 Weiss SJ. Tissue destruction by neutrophils. $N$ Engl $\mathcal{F}$ Med 1989;320:365-76.

6 Crabtree JE, Peichl P, Wyatt JI, Stachl U, Lindley IJD. Gastric interleukin-8 and IgA IL-8 autoantibodies in Helicobacter pylori infection. Scand f Immunol 1993; 37:65-70.

7 Crabtree JE, Farmery SM, Lindley IJD, Figura N, Peichl P, Tompkins DS. CagA/cytotoxic strains of Helicobacter pylori and interleukin-8 in gastric epithelial cell lines. f Clin Pathol 1994;47:945-50.

8 Taylor DE. Genetics of Campylobacter and Helicobacter. Annu Rev Microbiol 1992;46:35-64.

9 Covacci A, Censini S, Bugnoli M, Petracca R, Burroni D, Macchia G, et al. Molecular characterization of the 128$\mathrm{kDa}$ immunodominant antigen of Helicobacter pylori associated with cytotoxicity and duodenal ulcer. Proc Natl Acad Sci USA 1993;90:5791-5.

10 Tummura MKR, Cover TL, Blaser MJ. Cloning and expression of a high-molecular-mass major antigen of Helicobacter pylori: evidence of linkage to cytotoxin production. Infect Immun 1993;61:1799-809.

11 Crabtree JE, Figura N, Taylor JD, Bugnoli M, Armellini $\mathrm{D}$, Tompkins DS. Expression of $120 \mathrm{kDa}$ protein and cytotoxicity in Helicobacter pylori. $\mathcal{F}$ Clin Pathol 1992; 45:733-4.

12 Figura N, Guglielmetti A, Rossolini A, Barberi A, Cusi G, Musmanno RA, et al. Cytotoxin production by Campylobacter pylori strains isolated from patients with Campylobacter pylori strains isolated from patients with peptic ulcers and from patients with
only. $f$ Clin Microbiol 1989;27:225-6.

13 Telford JL, Ghiara $P$, Dell'Orco $M$, Comanducci $M$, Burroni D, Bugnoli M, et al. Gene structure of the Helicobacter pylori cytotoxin and evidence of its key role in gastric disease. F Exp Med 1994;179:1653-8.
14 Crabtree JE, Taylor JD, Wyatt JI, Heatley RV, Shallcross TM, Tompkins DS, et al. Mucosal IgA recognition of Helicobacter pylori $120 \mathrm{kDa}$ protein, peptic ulceration and gastric pathology. Lancet 1991;338:332-5.

15 Figura N, Bugnoli M, Cusi MG, Pucci AM, Lusini P, Quaranta S, et al. Pathogenic mechanisms of Helicobacter pylori: production of cytotoxin. In: Malfertheiner P pylori: production of cytotoxin. In: Malfertheiner P, Ditschneit H, eds. Helicobacter pylori, gastritis
ulcer. Berlin: Springer-Verlag, 1990:86-95.

16 Cover TL, Dooley CP, Blaser MJ. Characterization of and human serologic response to proteins in Helicobacter pylori broth culture supernatants with vacuolizing cytotoxin activity. Infect Immun 1990;58:603-10.

17 Lee A. $H$ pylori-initiated ulcerogenesis: look to the host. Lancet 1993;341:280-1.

18 Farmery SM, Pyrah EM, Crabtree JE. Detection of CagA positive Helicobacter pylori: a comparison of polymerase chain reaction and immunoblotting protocols. Gut 1994; 35:S34.

19 Clayton CL, Kleanthous H, Coates PJ, Morgan DD, Tabaqchali S. Sensitive detection of Helicobacter pylori by using polymerase chain reaction. F Clin Microbiol 1992; 30:192-200

20 Klinkert MQ, Herrmann R, Schaller H. Surface proteins of Mycoplasma hyponeumoniae identified from Escherichio coli expression plasmid library. Infect Immun 1985;49: 329-35.

21 Figura N, Armellini D, Bugnoli M, Bayeli PF, Gennari C, Crabtree JE. Activity of omeprazole on Helicobacter pylor and relation to toxicity of strains. F Clin Pathol 1994; 47:440-2.

22 Peichl P, Ceska M, Effenberger F, Haberhauer G, Broell $\mathrm{H}$, Lindley IJD. Presence of NAP/IL-8 in synovial fluids indicates a possible pathogenic role in rheumatoid indicates a possible pathogenic role in

23 Cover TL, Vaughn SG, Cao P, Blaser MJ. Potentiation of Helicobacter pylori vacuolating toxin activity by nicotine and other weak bases. F Infect Dis 1992;166:1073-8.

24 Cover TL, Cao P, Lind CD, Tham KT, Blaser MJ Correlation between vacuolating cytotoxin production by Helicobacter pylori isolates in vitro and in vivo. Infect Immun 1993;61:5008-12.

25 Rautelin H, Blomberg B, Fredlund H, Jarnerot G, Danielsson D. Incidence of Helicobacter pylori strains activating neutrophils in patients with peptic ulcer disease. Gut 1993;34:599-603.

26 Mai UEH, Perez-Perez GI, Allen JB, Wahl SM, Blaser MJ, Smith PD. Surface proteins from Helicobacter pylor exhibit chemotactic activity for human leukocytes and are present in gastric mucosa. $\mathcal{F} \operatorname{Exp}$ Med 1992;175: are present

27 Nielsen H, Andersen LP. Chemotactic activity of Helicobacter pylori sonicate for human polymorphonuclear leucocytes and monocytes. Gut 1992;33:738-42.

28 Craig PM, Territo MC, Karnes WE, Walsh JH Helicobacter pylori secretes a chemotactic factor for monocytes and neutrophils. Gut 1992;33:1020-3.

29 Nielsen H, Andersen LP. Activation of human phagocytic oxidative metabolism by Helicobacter pylori. Gastroenterology 1992;103:1747-53.

30 Crabtree JE. Mucosal immune responses to Helicobacter pylori. Eur $\mathcal{f}$ Gastroenterol Hepatol 1993;5(Suppl 2): pylori.

31 Figura N, Crabtree JE. Vacuolating toxin of Helicobacter pylori. In: Hunt R, Tytgat G, eds. Helicobacter pylori: basic mechanisms to clinical cure. Lancaster: Kluwer Academic Publishers, 1994:222-31.

32 Baggiolini $M$, Dewald B, Moser B. Interleukin-8 and related chemotactic cytokines-CXC and CC chemokines. Adv Immunol 1994;55:97-179.

33 Agace W, Hedges SR, Ceska M, Svanborg C. Interleukin8 and the neutrophil response to mucosal Gram-negative infection. 7 Clin Invest 1993;92:780-5.

34 Eckmann L, Kagnoff MF, Fierer J. Epithelial cells secrete the chemokine interleukin- 8 in response to bacterial entry. Infect Immun 1993;61:4569-74.

35 Agace W, Hedges SR, Andersson U, Andersson J, Ceska M, Svanborg C. Selective cytokine production by epithelial cells after exposure to Escherichia coli. Infect epithelial cells after expos
Immun 1993;61:602-9. 